\title{
Creating space for student autonomy and engagement through partnership and letting go.
}

\section{Colin Bryson}

For my first 20 years as a Higher Education (HE) teacher I always tried to be an innovative educator but within the context of a rather teaching centred orientation (Kember, 1997) - echoing the values and beliefs of the system that I had been inducted into. I researched on my academic subject, precarious employment, and linked that to being active trade unionist. These were two areas I felt passionate about, not my teaching or students. And then something changed. I discovered student engagement (SE).

SE is the sense of being and the will and disposition to 'become' rather than 'have' (Fromm, 1977), that enables persistence, personal and educational development, and transformational learning (Perry, 1999). Each student is unique - in what they bring to HE in terms of goals, aspirations, values and beliefs and how these are shaped and mediated by their holistic experience whilst a student. SE is constructed and reconstructed through the lenses of the perceptions and identities held by students and the meaning and sense a student makes of their experiences and interactions.

In 2003 I was given responsibility for developing more independent learning among the undergraduates in a large Business School. Senior managers desired this for the expedient reasons of extracting more and different contributions from the staff. I had some reservations about the pedagogical implications of reducing contact time and support and so took what was an unusual step at the time - I decided to ask the students.

\section{Researching}

I conducted focus groups covering 60 students, asking broad questions. The student view on independent learning was negative; you are pushing us away. However the revelation that emerged was SE, or a lack of it. The students described that in stark, emotive terms; no-one knows my name here, I am just a number. Another worrisome trend was the degree of transactionalism, what we called 'false' engagement; every mark counts. This powerful evidence compelled me to find out more, and to become an advocate of promoting SE.

There was surprisingly little research in the UK that was really about SE. An exception was Mann's (2001) notion of alienating forces in HE impacting negatively on students. The international literature was much more fruitful particularly from Australia (e.g. Krause et al 2005). So was the long tradition of work in the US on the impact of college on students (Pascarella and Terenzini, 2005) and Kuh's development of the National Survey of Student Engagement (2008). We assimilated these ideas to argue that SE is holistic and socially constructed (Bryson and Hand, 2007).

Further research studies, including a longitudinal study following students throughout their degree, have added to our understanding (Bryson and Hardy, 2012). These studies emphasised Tinto's (2003) point that the social is as critical as academic engagement. I have also explored the connection between SE and 'graduateness'. The leading commenters argue that it is the integrated development of the whole 
person (Yorke and Knight, 2006) that enable higher level graduate attributes (Barrie, 2006) and the initial formation of a graduate identity (Holmes, 2001). In fostering that development, it would appear to bear a remarkable resemblance to experiences and processes associated with high SE (Kuh, 2008). This promotes the rather radical notion that it is not the 'knowledge' gained but the learning process that is key, and the extra- or co-curricular is rather crucial in offering authentic opportunities to gain 'practice'. Learning in the 'subject' is important as it draws and maintains the student's interest and offers intellectual development.

Somewhere along this journey the Researching, Advancing and Inspiring Student Engagement (RAISE) network was created. As co-founder and inaugural chair I sought to define and map SE conceptually (Bryson, 2011). This exercise did show the importance of separating the dualism of 'students engaging' with 'engaging students'.

\section{Putting it into practice}

Although this clarion call from students was changing my own values and promoting a radical new approach, coming to Combined Honours $(\mathrm{CH})$ at Newcastle in 2008 presented a new opportunity. Students study two or three subjects from a long list in $\mathrm{CH}, 4500$ combinations are possible with nearly everyone on their own unique pathway. Previous student feedback was grim, the worst NSS scores in the university, a sense of alienation and unfair discrimination, lack of belonging and identity and a real failure of systems such as personal tutoring. It seemed impossible to change much in the curriculum because it is taught 'out there' in the academic schools.

Therefore I decided to invite the students to identify what the big issues were and what solutions they proposed. There were quick wins such as changing the name of the degree as they felt the former name rather pejorative. We introduced a new model of Student Staff Committee (SSC); student-led and with elected representatives with their own constituencies. We co-manage annual cohort surveys (80\% participation) to identify issues. We have Student Forums on specific issues to which all 400 students are invited. The Combined Honours Society (CHS) was reborn. This is completely student-led and promotes the social and community fostering agenda with a growth of membership to $30 \%$ from $2 \%$.

The SSC proposed peer mentoring and we developed such a successful scheme that the whole university are now adopting this for all students. The mentors run transition and induction, and have taken over from personal tutors in large measure. We introduced Peer Assisted Study Support leaders and a system of graduate mentors to support students with ongoing transitions.

Students and I have also co-designed modules. We introduced a final year independent project with features such as peer assessment, a reflective interview, and a very negotiable remit for topic and criteria. The fifty or so students who are involved in $\mathrm{CH}$ roles can undertake further co-designed modules, in which they are guided and assessed on their development and reflection through practice.

These approaches appear to have enhanced SE very strongly for some (who become 'super-engaged' and involved) and quite well for others. The NSS overall satisfaction score did rise to $96 \%$. Those who do get involved report an enhancement of graduate attributes. 
Is this substantial progress then to the epitome of SE? And what is that? Is that a learning community as advocated by Perry (op cit) where mutuality flourishes, or some form of partnership?

\section{Partnership}

The concept of partnership needs unpacking. In my industrial relations past, I have always been wary of the notion of employee partnership, not only because there is never an equal distribution of power even at the collective level, and the goals of employer and employees are nearly always different and often conflictual. There have been attempts to power-share and achieve industrial democracy but that involves collective power (i.e. between union and employer) e.g. co-determination. True democratic participation - the cooperative - is very rare.

In HE the goals of educator and students are mutual although power is not shared equally. My initial attempts have features of co-determination, of co-design and cocreation - close to the top of the 'ladder of student participation' (Bovill and Bully, 2011). I am less sure that they are co-production (McCullough, 2009) but may be on a par with attempts to do that elsewhere (Neary, 2011) although for my students the majority of their curricular and broader experience is 'traditional'.

A confusing tension and ambiguity in the SE debate is that the national bodies see SE as collective representation (e.g Higher Education Academy, 2010). This may be one aspect but is too narrow. Wenstone (2012) argues for an approach of democratic representation broadly across the institution in synchrony with partnership at the level of individual. She acknowledges that this will require democraticisation in staff structures too!

At the unit of degree it seems possible to do both. There are some practical constraints. Students taking this much responsibility and ownership is demanding for them and involves steep learning curves. Should we offer (more than intrinsic) reward for these challenging roles, and to attract more take-up of opportunities? Peer tensions arise too as students do not have, inherently, 'the authority of office' or 'credibility' that staff have. Are there limits to areas that students should be partners? Student turnover offers renewal but discontinuity. Heterogeneity needs to be embraced but what level of engagement and participation in a democratised $\mathrm{HE}$ community should be obligatory. Can one opt out? These are challenging questions but should not deflect us from pursuing partnership and seeking solution with the students.

\section{Reflections}

I conclude with some reflection of the impact of this agenda on staff and on me. It involves both a change in values and beliefs and on practices. It involves consciously letting go. That entails giving a lot of trust. It can be frustrating, standing back and feeling you are letting the students 'flounder'. It involves a lot of investment of time and effort. But it really is worth it. For years I worked hard in an environment where both students and staff were alienated and disempowered - and that was much more frustrating. In a relatively short period, adopting holistic SE and partnership working has been really emancipatory for all parties. Even senior management have noticed. It has tremendous reward for me. Working in partnership with engaged students is a true privilege. It has transformed my own engagement as an educator and had a very positive impact on so many of the students. Adopting this ethos across higher 
education would be so beneficial and offers a rather better and more valuable purpose to all within and beyond $\mathrm{HE}$.

Barrie, S. (2006) Understanding what we mean by the generic attributes of graduates. Higher Education, 51, 215-241.

Bovill, C. and Bulley, C. (2011) A model of active student participation in curriculum design: exploring desirability and possibility. In Rust, C. Improving Student Learning (18) Global theories and local practices: institutional, disciplinary and cultural variations. Oxford: The Oxford Centre for Staff and Educational Development, 176-188

Bryson, C, (2011) Clarifying the concept of student of engagement: $A$ fruitful approach to underpin policy and practice. Paper presented at theHEA Conference, Nottingham, July $5-6^{\text {th }}$

Bryson, C. and Hand, L. (2007) The role of engagement in inspiring teaching and learning. Innovations in Teaching and Education International, 44(4), 349-362. Bryson, C. and Hardy L. (2012) The nature of student engagement, what the students tell us, in Solomonides, I. Reid, A. and Petocz, P. (eds) Engaging with Learning in Higher Education London: Libri.

Fromm, E. (1977). To have or to be? London: Jonathan Cape HEA (2010) Research and evidence base for student engagement. Available at: http://www.heacademy.ac.uk/ourwork/universitiesandcolleges/alldisplay?type=res ources\&newid=ourwork/studentengagement/Research and evidence base for student engagement\&site=york Accessed 9/12/10

Holmes, L (2001) Reconsidering Graduate Employability: the 'graduate identity' approach, Quality in Higher Education, 7(2), 111-119.

Kember, D. (1997) A reconceptualisation of the research into university academics' conceptions of teaching, Learning \& Instruction, 7, (3), 255-275.

Krause, K. Hartley, R. James, R. and Mclnnis, C. (2005) The first year experience in Australian universities: findings from a decade of national studies

Canberra:.DEST

Kuh, G. (2008) High impact practices. What they are, who has access to them and why they matter? Washington: AACU

Mann, S. (2001) Alternative Perspectives on the Student Experience: alienation and engagement. Studies in Higher Education, 26, (1), 7-19.

McCulloch, A. (2009) The student as co-producer: learning from public administration about the student-university relationship. Studies in Higher Education 34 (2), 171-183.

Neary, M. (2011) Student as Producer: Student engagement and the idea of the University. Paper presented at Student Engagement Conference, Galway University, June $9-10^{\text {th }}$

Pascarella E. and Terenzini, P. (2005) How College Affects Students San

Francisco: Jossey Bass

Perry, W. (1999) Forms of intellectual and Ethical Development in the College

Years: a scheme New York: Harcourt Brace

Tinto, V (2003) Learning better together: The impact of learning communities on student success in higher education. In Promoting Student Success in College, Higher Education Syracuse University: Higher Education Monograph Series 1-8 Wenstone, R. (2012) A manifesto for partnership. Available at http://www.nusconnect.org.uk/news/article/highereducation/Rachel-Wenstonelaunches-a-Manifesto-for-Partnership/ Accessed 18/11/12 Yorke, M. and Knight, P. (2006) Embedding employability into the curriculum. York: The Higher Education Academy 